\title{
ОСТАТОЧНІСТЬ РІШЕННЯ ГОСПОДАРСЬКОГО СУДУ У РЕКОДИФІКОВАНОМУ ГПК УКРАЇНИ
}

\author{
ВОЛЕВСЬКИЙ Лев Володимирович - аспірант кафедри господарського \\ права, Національний юридичний університет імені Ярослава Мудрого, м. Харків \\ ORCID orcid.org/0000-0002-1172-3744 \\ DOI 10.32782/NP.2020.4.19
}

В статье анализируется проблема окончательности решения суда хозяйственной юрисдикиии с позиции необходимости соблюдения правила запрета пересмотра акта правосудия, приобретшего указанную особенность. Поддерживается точка зрения относительно необходимости внедрения на законодательном уровне признаков окончательности решения суда. Основываясь на анализе материалов практики делается въгвод о нецелесообразности распространения случаев восстановления сроков на обжалование решений, вступивших в законную силу. Вместе с тем, исследуются отдельные аспекты действия хозяйственного процессуального законодательства во времени с учетом предмета данной статьи. Также обращается внимание на отличие и не идентичность понятий законной силь и окончательности судебного решения. Признается справедливой практика ЕСПЧ относительно критики практики нащиональных судов относительно восстановления сроков обжалования актов правосудия после истечения длительного времени с момента их вынесения при осведомленности заинтересованньх лич о содержании судебнъих решений.

Ключевъе слова: хозяйственное процессуальное законодательство; участники хозяйственного процесса; окончательность судебного решения; восстановление срока на обжалование решения; действие процесуального закона во времени.
Постановка проблеми в загальному вигляді та їі зв'язок із важливими науковими та практичними завданнями полягає в існуванні доволі розповсюдженої проблеми відносно конкуренції норм процесуального законодавства щодо забезпечення, з одного боку, реалізації конституційного права на оскарження судових рішень. 3 іншого, у необхідності вирішення питання поновлення строків на оскарження актів правосуддя за умови пропуску строку суб'єктом зазначеного права з поважних, на його думку, причин. У зв'язку з цим відомі випадки зловживання правом оскарження зазначених актів, які полягають у реалізації його особами після спливу тривалого часу з моменту набрання судовим рішенням властивостей законної сили та ознак остаточності. Як наслідок, під час доволі складно застосовувати норми господарського процесуального законодавства у часі при визначенні можливості подальшого руху справи у суді контролюючої інстанції.

Аналіз останніх досліджень та публікацій, що започаткували вирішення цієї проблеми, на які спирається автор, свідчить про необхідність приділення уваги окремим особливостям застосування господарського процесуального законодавства при реалізації права на оскарження судового рішення. Ці питання ретельно досліджувались у роботах О.О.Борисової, 


\section{Цивільне, підприсмницьке, господарське та трудове право}

К.В.Гусарова, В.В.Комарова [1-3] та інших дослідників.

Не вирішені раніше частини загальної проблеми, яким присвячена стаття, полягають у відсутності законодавчого закріплення умов протидії намаганням зловживання процесуальними правами в частині оскарження судових рішень, котрі набрали законної сили.

Постановкою завдання $\epsilon$ розробка на теоретичному рівні концепції протидії спробам подолання законної сили та остаточності судового рішення поза межами встановлених господарським процесуальним законодавством строків оскарження актів правосуддя.

Викладення основного матеріалу з повним обгрунтуванням отриманих результатів грунтується на використанні методів наукового пізнання. За загальним правилом, рішення суду набирає законної сили після спливу строку на апеляційне оскарження, або, при такому оскарженні, 3 дня прийняття постанови судом апеляційної інстанції. Слід зазначити, що, на відміну від національного законодавства, Конвенція про захист прав людини та основоположних свобод оперує терміном «остаточність» судового рішення та не містить такої властивості, як законна сила. Вітчизняне господарське процесуальне законодавство, навпаки, не містить нормативного закріплення змісту остаточності, оперуючи терміном законної сили судового рішення. У юридичній літературі на співвідношення зазначених властивостей звертає увагу в одній із своїх робіт К.В.Гусаров [4]. Застосування правил ГПК України після його рекодифікації може бути ускладненим необхідністю застосування господарського процесуального законодавства у дорекодифікаційній редакції. Мова іде, зокрема, про справи щодо інстанційного оскарження актів правосуддя, можливість оскарження яких по-різному визначаються господарським процесуальним законодавством у попередній редакції ГПК України та чинній.
Поряд із зазначеним, практичний сенс має відповідь на наступне питання. У разу подання апеляційної скарги особою, яка не була повідомлена про розгляд справи після спливу одного року з дня складення повного тексту судового рішення, чи вирішується питання його поновлення відповідно до статті 256 ГПК України. При цьому особа отримала копію рішення, а 3 апеляційною скаргою звернулась лише із спливом багатьох місяців. В цьому випадку чи суд зобов'язаний відкрити апеляційне провадження безумовно?

Дослідження вказаної ситуації впливає на можливість подолання ознак остаточності судового рішення. Поширення випадків поновлення строків на апеляційне оскарження в аналогічних ситуаціях навряд чи можна визнавати справедливими, оскільки порушуе положення правової визначеності акту правосуддя.

Конституційне закріплення права апеляційного оскарження конкретизується у нормах господарського процесуального права. Частина 2 ст. 256 ГПК України передбачає можливість поновлення пропущеного строку на апеляційне оскарження для учасника справи, якому повне рішення або ухвала суду не було вручено у день його (іï) проголошення або складання:1) на рішення суду - якщо апеляційна скарга подана протягом двадцяти днів 3 дня вручення йому повного рішення суду; 2) на ухвали суду - якщо апеляційна скарга подана протягом десяти днів з дня вручення йому відповідної ухвали суду. Строк на апеляційне оскарження може бути поновлений у випадках пропуску з інших поважних причин, крім випадків, зазначених у ч.2 ст. 261 ГПК України. Аналіз зазначених нормативних приписів свідчить про віднесення законодавцем до поважних причин випадки, визначені у ч.ч. 2 та 3 ст. 256 ГПК України. Слід визнати, що вирішення подібних випадків мають певну долю складності.

Застосування ч.2 ст.261 ГПК України, вважаю, не повинно пов'язуватись із можливою оцінкою судом апеляційної інстанції поважності причин пропуску строку на апеляційне оскарження заінтересова- 
ною особою. У той же час уявляється, що застосування п.1 ч.2 вказаної норми має пов’язуватись із визначенням початку перебігу строку на апеляційне оскарження. Реалізація особою права апеляційного оскарження може бути здійснено в такому випадку впродовж 20 днів 3 дня вручення їй повного рішення суду.

За матеріалами однієї із справ, що розглядається Верховним Судом зазначається, що рішення ухвалено судом першої інстанції за відсутності заявника скарги 14 березня 2018 р. 23 липня 2018 р. представник заявника звернувся до суду із клопотанням про ознайомлення 3 матеріалами справи, а 13 серпня 2018 р. представник подав до суду заяву про перегляд судового рішення за нововиявленими обставинами із додаванням копії повного тексту рішення від 14 березня 2018 р. Апеляційна скарга на вказане рішення була подана 14 травня 2020 р., тобто з пропуском строку на апеляційне оскарження. У клопотанні про поновлення строку на апеляційне оскарження рішення суду першої інстанції представник відповідача зазначив, що про це рішення йому стало відомо випадково.

Таким чином, під час отримання повного тексту рішення суду до реалізації права апеляційного оскарження сплинуло більше одного року. 3 огляду на цю обставину вважаю неможливим початок руху справи в суді апеляційної інстанції, враховуючи положення п.1 ч.2 ст. 261 ГПК України. Цей висновок пояснюється наступним.

Право на апеляційне оскарження диспозитивне право особи, як і звернення такої особи до суду першої інстанції за умови, якщо вона суб'єктивно вважає своє право порушеним. Сюди можна також віднести і звернення особи із заявою про перегляд справи за нововиявленими обставинами. Проте реалізація диспозитивного права, зокрема на звернення до апеляційного суду, пов'язується господарським процесуальним законодавством із дотриманням певних умов. Передусім це здійснення такого права відповідно до встановлених строків апеляційного оскарження. Вважаю, що правила перебігу строку для осіб, визначених у п.1 ч.2 ст.261 ГПК
України, визначаються п.1 ч.2 ст. 256 вказаного нормативного акту.

Не реалізація суб'єктом господарського процесуального права права апеляційного оскарження у 20-денний термін 3 дня вручення йому повного тексту судового рішення свідчить про його відмову від права на апеляційне оскарження судового рішення. Особа вважала за можливе реалізацію іншого диспозитивного права - подачу заяви про перегляд справи за нововиявленими обставинами. Апеляційне оскарження, як і інші форми перегляду судового рішення, не слід розглядати як завуальовані способи затягування набрання актом правосуддя законної сили та властивостей остаточності. Тому звернення апелянта із скаргою у строк, що перевищує річний термін від дати отримання нею повного тексту судового рішення, викликає необхідність відмови у відкритті апеляційного оскарження у разі, якщо апеляційна скарга подана після спливу одного року 3 дня отримання повного тексту судового рішення (п.1 ч.2 ст.256 та п.1 ч.2 ст.261 ГПК України).

Вищевказані висновки кореспондуються і з позиціями Европейського суду 3 прав людини (EСП $\mathcal{A})$. Так, у п.п. 40 та 41 рішення по справі «Пономарьов проти України» зазначається, що у випадку поновлення строку на ординарне апеляційне оскарження зі спливом значного періоду часу та на підставах, що не вважаються переконливими, таке рішення може порушити принцип юридичної визначеності. Разом з тим ЕСП $\Lambda$ визнає, що вирішення питання про поновлення строку на оскарження перебуває в межах дискреційних повноважень національних судів, однак такі повноваження не $\epsilon$ необмеженими. Від судів вимагається вказувати підстави. Однією із таких підстав може бути, наприклад, неповідомлення сторін органами влади про прийняте у їх справі рішення. Однак навіть у такому випадку можливість поновлення не буде необмеженою, оскільки сторони в розумні інтервали часу мають вживати заходів для ознайомлення із станом відомого їм судового провадження. 


\section{Цивільне, підприсмницьке, господарське та трудове право}

У п. 47 рішення у справі «Устименко проти України» суд постановив, що рішення відносно поновлення терміну оскарження може порушити принцип правової визначеності та свобода розсуду судів при вирішенні питання про поновлення не $є$ обмеженою. У кожному випадку суди повинні встановлювати, чи виправдовують причини поновлення строку на оскарження втручання у принцип остаточності судового рішення. У рішенні по справі «Кузнецов та інші проти Росії» від 13 серпня 2018 р. ЄСПЛ підкреслив в якості умови відступу від принципу res judicata поновлення строків на оскарження. Тому особи, котрі оскаржують рішення за межами строків, наданих законом, повинні діяти з достатнім поспіхом. При цьому зазначається, що подача особами скарги після спливу 4 місяців з дня визнання неприйнятними їх апеляційних скарг свідчить про їх дії без належної старанності. У такому випадку задоволення їх клопотання про поновлення строку на оскарження означало 6 глумління над принципом правової визначеності.

Висновки дослідження та перспективи подальших розробок у цьому напрямку зводяться до наступного. На підставі викладеного вважаю, що з урахуванням описаних обставин господарської справи у разі подання апеляційної скарги особою, яка не була повідомлена про розгляд справи після спливу одного року з дня складання повного тексту рішення та отримання нею вказаного процесуального документу, суд не зобов'язаний відкрити апеляційне провадження безумовно. Уявляється, що в такому випадку доцільно застосовувати інститут відмови у відкритті апеляційного провадження на тій підставі, що апеляційна скарга подана після спливу одного року 3 дня складання повного тексту судового рішення. При цьому апелянт не реалізував власне диспозитивне право на оскарження судового рішення в апеляційному порядку протягом одного року з дня отримання повного тексту судового рішення.

\section{Література}

1. Проверка судебных постановлений в гражданском процессе стран ЕС и СНГ: моногр. / З. Х. Баймолдина и др., под ред. Е. А. Борисовой. 2-е изд., перераб. и доп. М.: Норма: Инфра-М, 2012, 768 с.

2. Гусаров К.В. Інстанційний перегляд судових рішень у цивільному процесі: дис. док-ра юрид. наук. 12.00. 03.-цивільне право і цивільний процес; сімейне право. Х.: Нац. ун-т «Юридична академія України імені Ярослава Мудрого», 2011. - 431 с.

3. Цивільне судочинство України: основні засади та інститути: монографія / В. В. Комаров, К. В. Гусаров, Н. Ю. Сакара та ін.: Х.: Право, 2016, 848 с.

4. Гусаров К.В. Вплив конституційної скарги на остаточність судового рішення та вичерпання національних засобів юридичного захисту у цивільному процесі //Biсник Національної академії правових наук України, 2017, №1 (88). - С. 120-130.

5. Рішення Європейського суду з прав людини по справі «Пономарьов проти України» //Ел. pecypc: https://zakon.rada. gov.ua/laws/show/974_434\#Text

6. Рішення Свропейського суду з прав людини по справі «Устименко проти України»//Ел. pecypc: https://zakon.rada.gov.ua/ laws/show/974_b27\#Text

7. Рішення Європейського суду з прав людини по справі «Кузнецов проти Роciï»//E . pecypc: https://europeancourt.ru/ resheniya-evropejskogo-suda-na-russkomyazyke/kuznecov-i-drugie-protiv-rossiipostanovlenie-evropejskogo-suda/

\section{Volevskyi Lev. \\ FINALITY OF DECISION OF AN ECO- NOMIC COURT IN THE RECODIFIED EPC OF UKRAINE}

In the article there is being analyzed a problem of finality of court decision of economic jurisdiction from the point of view a necessity of compliance with the rule prohibiting the review of the act of justice, which has acquired this property. The point of view on the necessity of introduction at the legislative level of signs of finality of the court decision is supported. Based on the analysis of materials of court practice, it is concluded that it is inexpedient to extend the cases of renewal of terms for appeals 


\section{АНОТАЦІЯ}

у статті аналізується проблема остаточності рішення суду господарсъкой юрисдикиіӥ з позииіӥ необхідності дотримання правила заборони перегляду акту правосуддя, щзо набрав означеної властивості. Підтримуеться точка зору стосовно необхідності запровадження на законодавчому рівні ознак остаточності рішення суду. На підставі аналізу матеріалів судової практики робиться висновок про недочільність розповсюдження випадків поновлення строків на оскарження відносно рішень, котрі тривалий час є такими, що набрали законної сили. Разом з иим, досліджується аспект діӥ господарсъкого процесуального законодавства в часі, враховуючи предмет даної статті. Також звертається увага на відмінність та неоднаковість понять законної сили та остаточності судового рішення. Визнається справедливою практика ЕСПЛ щзодо критики практики національних судів з приводу поновлення строків на оскарження відносно актів правосуддя після спливу тривалого часу з моменту їх ухвалення при наявності обізнаності заінтересованих осіб про зміст судових рішень.

Ключові слова: господарсъке процесуальне законодавство; учасники господарського прочесу; остаточність судового рішення; поновлення строку на оскарження рішення; дія процесуального законодавства в часі. against decisions that have long been in force. At the same time, certain aspects of the economic procedural legislation in time are studied, taking into account the subject of this article. Attention is also drawn to the difference and non-uniformity of the concepts of legal force and finality of the court decision. The rightful practice of ECHR is recognized on criticizing practice of national courts on the renewal of terms for appeals against acts of justice after passing long time since their adoption, in the presence of awareness of interested people about the content of the court decisions.

Key words: economic procedural legislation; participants of economic process; finality of court decision; renewal of the term for appealing the decision of the procedural legislation in time. 